\title{
Chromosome 16
}

National Cancer Institute

\section{Source}

National Cancer Institute. Chromosome 16. NCI Thesaurus. Code C13211.

The designation for each member of the sixteenth largest human autosomal

chromosome pair. Chromosome 16 spans about 90 million base pairs and represents

just under $3 \%$ of the total DNA in normal diploid cells. 